\title{
UNDERSTANDING WORK-LIFE BALANCE, RESILIENCE AND EMOTIONAL ENDURANCE OF SINGLE WORKING MOTHERSIN THE WORKPLACE: A QUALITATIVE STUDY
}

DOI: 10.17261/Pressacademia.2021.1387

JMML-V.8-ISS.1-2021(5)-p.64-75

\section{Arzu Girisken}

Altınbas University, Business Administration, Istanbul, Turkey. arzu.cakar@altinbas.edu.tr, ORCID: 0000-0003-0295-7976

\begin{tabular}{l}
\hline Date Received: December 24, $2020 \quad$ Date Accepted: March 17, 2021 \\
\hline To cite this document \\
Girisken, A., (2021). Understanding work-life balance, resilience and emotional endurance of single working mothers in the workplace: a qualitative \\
study. Journal of Management, Marketing and Logistics (JMML), V.8(1), p.64-75. \\
Permanent link to this document: $\underline{\text { http://doi.org/10.17261/Pressacademia.2021.1387 }}$ \\
Copyright: Published by PressAcademia and limited licensed re-use rights only. \\
\hline
\end{tabular}

\section{ABSTRACT}

Purpose- The concepts of work-life balance and resilience at work are increasing in popularity. However, the literature, unfortunately, lacks gender perspective and geographical diversification. This paper aims to fill in this gap in the literature and inspire further resea rch on a gender perspective. A semi-structured survey was developed to evaluate life-work balance and resilience in single working mothers' workplace practices in Istanbul. The research was conducted with 32 single mothers working in the private sector. Results suggest that most single mothers feel exhausted and stretched between their work and children while they often seek a reprieve in religion to keep their spirits up.

Methodology- For this study, qualitative research was developed with 32 single working mothers in Istanbul, Turkey. Open-ended questions were asked to the 32 mothers in face-to-face interviews. All of the women who participated in this study work in private institutions with more than 200 employees. A semi-structured interview was developed with open-ended questions to evaluate work-life balance and resilience practices among single mothers based on The Maslach Burnout Inventory (Maslach \& Jackson, 1981; Winwood et al., 2013; Wolfson \& Mulqueen, 2016).

Findings- Results suggest that single mothers feel exhausted and stretched between their work and children. On the other hand, they develop authentic solutions to overcome their frustrations.

Conclusion- In Turkey, single working mothers feel a strong responsibility towards their children to stay resilient and limit their complaints. It's been widely discussed in the existing literature that internal motivational factors fuel resilience. However, in Turkey, societal support acts a s an external factor to make single working mothers more resilient, and the resilience they develop enhances their performance in the workplace.

Keywords: Women at work, single working mothers, managerial resilience, work-life balance

JEL Codes: J2, M00, M14

\section{INTRODUCTION}

Despite two centuries of strenuous efforts, most women are still out of the workforce, and those who have managed to become a part of it face serious barriers throughout their careers (Tomlinson \& Durbin, 2010; Sojo \& Wood, 2012). Women are still su bject to extended and intense working hours and job insecurity while also divided between their work and personal lives.

In parallel with the agile transformation of the workplace, family structures have also changed. Throughout the last decades, the number of single mothers has significantly risen worldwide (Palmeret al., 2012). This increasing number of single working mothers creates additional problems to be resolved. For example, single working mothers have their unique issues on top of women's issues (Youngblut et al., 2000; Mostert, 2009; Brand \& Thomas, 2014). They al so have low labor force participation and are subject to lower incomes (Brady \& Burroway, 2012; Shirahase \& Raymo, 2014; Johnsen \& Reiso, 2019).

When society regards systemic problems as personal failures, suggestions in the current literature such as resilience aim to help individuals overcome the issues (Koubova \& Buchko, 2013). The rising interest in the concepts of resilience and work-life balance coincides with the new wave of problems brought about by the global financial crisis of 2008 (Milkie et al., 2010; Linnenluecke, 
2017). Millions of people lost their jobs and social rights, while those who managed to keep their positions have been subject to heavier workloads (Schrag \& Schmidt-Tieszen, 2014), and these problems have only increased with the pandemic.

This paper aims to highlight specific problems of single working mothers, introduce their real-life, work-life balance practices in developing workplace resilience, and create a conceptual basis to inspire further research to improve social awareness. The paper also aims to contribute to the geographical diversification of the literature.

To achieve this study's primary goal, a semi-structured qualitative research methodology was developed for evaluating the worklife balance practices of single working mothers in Istanbul. The qualitative findings were quite interesting and shed light on the problems single working mothers faced in their personal and professional lives. When a com pany that employs single mothers exhibits stronger empathy towards them, their professional performance improves, and this enhanced business performance can positively alter their work-life balance.

\section{LITERATURE REVIEW}

The concept of work-life balance refers to an employee's ability to have time for their family or social activities. Problems regarding work-life balance are more prominent for women than men due to existing traditional lifestyles, which leave child and house care responsibilities to women (Drange et al., 2016; Grant \& Guerin, 2018). Such problems are also seen as initiators of a series of issues, including psychological problems, stress, dissatisfaction, high job turnover, and absenteeism (Gittell et al., 2006; Koyuncu et al., 2012; Sperlich \& Geyer, 2015). Berkman et al. (2010) show that organizations that do not provide employees with the opportunity of balancing their work and life activities can lead to cardiovascular risks and sleep problems for employees.

The literature mainly sees the work-life balance puzzle as involving efficient time scheduling and time usage (Fagan \& Walthery, 2011). Lane (2011) attempts to overcome this limited perspective and seek real solutions from a broader scope. Accordingly, the concept of work-life balance has contested meanings in different perspectives, such as being synonymous with work-family compensation or work-life conflicts. However, modern life requires more complex and diversified roles. Even if one is to eliminate conflicts between the role of work and family, it does not necessarily mean a satisfying balance. Lane (2011) offers a more collective approach to challenge organizations to provide better work conditions and challenge the political authority to eli minate gender and class assumptions embedded in policies.

The term resilience originates from the Latin verb "resilience" (to leap back), and it was first used in mathematics in the 17 th century. The modern organizational sciences literature sees resilience from three different perspectives, $n$ amely a trait or a capacity, or a process (Tabassum et al., 2019). Indeed, the concept of organizational resilience is seen as having such characteristics attributed to men (Witmer, 2019). The idea of resilience, inherited from natural sciences, is flexibl e and elastic and a perfect ideological fit with male-headed neoliberalism (Jeyaranyan \& Swaminathan, 1999; Walker \& Cooper, 2011; Britt et al., 2016).

Following the 2008 global financial crisis, resilience was introduced as a 'cure' to many people who had lost their jobs and were subject to harsher employment regulations (Harrison, 2013). Single mothers, who require more social rights, were also among those who were categorized as not resilient enough to keep their positions under harsher conditions (Gill \& Orgad, 2018). Meanwhile, human resource departments were assigned to support employees who retained their roles in a financially struggling company by shouldering more significant responsibilities (Kossek et al., 2011; Nabavi \& Shahryari, 2012; Spangler et al., 2012; Bardoel et al., 2014; Vanhove et al., 2015).

Such external shocks as an economic crisis are also seen to extend the gender gap. Simultaneously, Kaya Bahçe and Memiş (2013) show that an identical rise in the risk of a spouse's unemployment increases women's work five times more than men. Mainstream research (Hansen, 2017) suggests that women struggle with resilience problems more than men at work. However, this may be just a perception and bias against women rather than the reality (Torchia et al., 2011; LDC, 2018). Isaacs (2014) shows that in academia, female deans are more resilient than male ones since women face more workplace challenges and consequently develop the ability to further deal with them.

The literature has a common understanding of the burnout effects of negativity in the workplace (Bia nchi \& Milkie, 2010; Noor \& Zainuddin, 2011). However, since almost all research is the fruit of the neoliberal era, suggestions are mainly personal and imply that some superior individuals can overcome burnout by building resilience (Halbesleben \& Buckley, 2004; Turner, 2014). Gill and Orgad (2018) also point out that the neoliberal approach describes women as "bounce -backable subjects" in the labor force to systematically forbid any attempts to criticize the system or voice the need for collective solutions. 
Resilience has a higher importance in post-trauma processes (Maitlis, 2011). The periods during pregnancy and raising children are not considered as formal traumas, but in practice, women, particularly single working mothers, face many consecutive trau mas throughout this time in their life (Roth et al., 2012; Chatman, 2015). Women must deal with many personal problems at work, from the glass ceiling in their career development to gender discrimination and the gender stress gap or gender pay gap (Smit $h$ et al., 2012; Carmeli et al., 2013; Lott \& Chung, 2016).

Along with dealing with all problems that women face at work, single working mothers have additional obstacles to overcome, such as harsh competitive conditions in the labor market (Liang et al., 2018). For example, they may face lower income, no so cial support or benefits, low self-esteem, less personal satisfaction, and more tremendous time pressures (Knoef \& van Ours, 2016). One of the main problems single working mothers face is wage discrimination and, as a result, economic insufficiency (Roman, 2017). In addition to wage discrimination within the same sector or even in the same organization, women's labor force is also concentrated in low-paying and labor-intensive industries such as textile or ready-wear (Kabasakal et al., 2011).

Single working mothers' family relations, income, housing, and health directly impact their work -life balance. Time commitments and family support positively impact their work lives, while simultaneously, work schedules, workplace, and income have an impact on their personal lives. Education also directly impacts single working mothers' ability to sustain a balance between work and life (Robbins \& McFadden, 2003; Montez et al., 2014).

Harsher neoliberal policies that limit public support and job security also act against single working mothers (Kroger, 2010; Sanders et al., 2011). Neoliberalism has loaded higher responsibilities on women's shoulde rs in addition to their traditional roles at home while labeling those who have difficulties with the heavy duties as failing (Bottrell, 2013). Hanicoglu and Hartman (2014) also show that single working mothers' careers are affected by factors such as suit able working hours, while childcare or welfare support opportunities provided by the company or government positively impact theircareer performance. Mogstad and Pronzato (2012) show that workforce reform systems developed to support single working mother s have proven successful in increasing labor force participation and income thanks to welfare receipts.

Such additional idiosyncratic troubles that women are required to overcome make it necessary to develop a gender perspective while researching the concepts of resilience at work and in work-life balance (Calas \& Smircich, 2014; Berryhill \& Durtschi, 2016). Intending to stress this requirement, this paper develops research on single working mothers to evaluate how single working mothers' different practices have on dealing with resilience at work and work-life balance needs.

According to the Turkish Statistical Institute (TUIK, 2020), 41.4 mils. Women lived in Turkey, a $49.8 \%$ share of the total population, as of 2019. Healthy life years at birth, the expectation of a healthy life without health problems limiting daily activities, stood at 56.8 years for women versus 59.9 years for men. However, life expectancy at birth for women was at 81 versus 75.6 for men. $85 \%$ of women had completed at least one educational level versus $96 \%$ for men, while $7.6 \%$ of women were illiterate versus $1.3 \%$ of men, and $18 \%$ had a higher education versus $22 \%$ of men.

Labor force participation for women stood at only $34 \%$ versus $73 \%$ for men, while women's unemployment rate was $14 \%$ versus $10 \%$ for men. Dominant conservatism in the public sphere is seen as the main driving force behind permanently low labor force participation rates for women in Turkey (Goksel, 2013). Women's expectation of being active in the labor market throughout their lives was 19 years versus 39 for men. Women earned 46,000 Turkish lira annually on average versus 50,000 for men; the gender pay gap was $7.7 \%$ (TUIK, 2020).In the Turkish parliament, only $17 \%$ of MPs were women, while only $3 \%$ of the country's mayors were women (KA.DER, 2020).

According to the Global Gender Gap Index 2020 (WEF, 2020), Turkey ranked 130th among 153 countries compared to 105th in the 2006 ranking. According to the 'Economic Participation and Opportunity' sub -index, Turkey ranked 136th while it ranked 113th in the 'Educational Attainment' sub-index. In the 'Political Empowerment sub-index, Turkey was 109th. Turkey's labor act provides women employees and mothers with some additional rights (ILO, 2003); however, it should be noted that Turkey ranks 107th among 128 countries in the Rule of Law Index (WJP, 2020).

Gender policies also remain just on paper, and implementation is far from the policies' goals on the written documents (Alnia cik et al., 2017; Ermis Mert, 2018). Akkan and Serim (2018) suggest that women employees, particularly young women with a low level of education who work at informal and precarious jobs, are considered among the most vulnerable groups in Turkey due to barriers to access to and ability to stay in the labor market. They argue that the government may fulfill its legal mission by providing 
public childcare facilities rather than increasing women's vulnerability by introducing harsher neoliberal policies, allegedly to increase women's participation in the workforce via promoting flexible employment.

Kabasakal et al. (2011) also suggest that women in Turkey who work in managerial and more prestigious positions face different problems regarding their conflicting work and life roles than unskilled or semi-skilled women workers in Turkey compared to women in high-level management positions in developed countries. Women managers who come from a more privileged background have more opportunities to practice better work-life balance, such as the ability to employ low-paid workers in their homes (Bespinar, 2010).

\section{DATA AND METHODOLOGY}

Single working mothers are quite emotional when they have the chance to talk about their private life. Mainly they are susceptible to their child/children. Therefore, to shed light on single working mothers' deep emotional reactions, a qualitative research method was used, and semi-structured in-depth interviews were conducted. Thus, open-ended questions were asked face-toface to 32 single working mothers who work in private institutions with more than 200 employees. The main reason for choosing single working mothers among more than 200 employees is to understand the possible peer-pressure element in the business environment.

The reason for conducting semi-structured interviews was to evaluate work-life balance and resilience practices among single mothers based on The Maslach Burnout Inventory (Maslach, 1981; Winwood et al., 2013; Wolfson \& Mulqueen, 2016). The semistructured interview method carries the opportunity to obtain more in-depth qualitative data since it includes both structured and unstructured interview methods (Isreal et al., 2017). It is also superior in providing the opportunity of developing a mo re indepth understanding of the research subjects rather than being swamped with limits imp osed by statistical rules (Savin-Baden and Major, 2013; Windle et al., 2011) suggest there is no "gold standard" in resilience measurement scales and adversities sh ould be negotiated more deeply with in-depth interviews. Data retrieved from the in-depth interviews mainly related to family or society level should also be included to understand better the concept of work-life balance (Keeney et al., 2013; Palinkas et al., 2013).

The in-depth interviews were conducted in 2019; therefore, there was no need to acquire a specific ethical committee's permission. However, ethical concerns were always at the center of the study throughout the entirety of the research. To keep the personal data of the participants confidential, interviews were not recorded. It was well-understood that not recording the interviews made the participants sincerer, and they had no reason to filter their answers; instead they frankly shared their thoughts on delicate and personal matters.

As it can be seen at Table 1. the participants' ages vary from 18-47, and 11 (33\%) participants were between the age of 18-29, while $15(48 \%)$ of the total 32 single mothers were between $30-40$, with the remaining $6(20 \%)$ older than 40.21 of the single mothers $(66 \%)$ were divorced while $6(19 \%)$ were the widow and the remaining $5(16 \%)$ had never married. 5 participants (17\%) had a high school degree, while $5(17 \%)$ had graduated from vocational schools, and 16 of the participants (49\%) had an undergraduate degree. The remaining $6(18 \%)$ had a graduate degree. 2 of the fathers $(6 \%)$ had only primary school education, 3 of them (9\%) had an elementary school education, $7(22 \%)$ had a high school de gree, $5(16 \%)$ had graduated from vocational schools, 11 of them (34\%) had an undergraduate degree, and the remaining $4(13 \%)$ had graduate degrees. 14 of the single mothers (45\%) had only one child, while 13 of them (40\%) had two children, and the remaining $5(15 \%)$ had three children.

Table 1: Sociodemographic Characteristics of Sampling

\begin{tabular}{lcc}
\hline Age & $\mathrm{N}$ & $\%$ \\
\hline $18-29$ & 11 & 33 \\
\hline $30-40$ & 15 & 48 \\
\hline $41-47$ & 6 & 20 \\
\hline Marital Status & & \\
\hline Married & 0 & 0 \\
\hline Divorced & 21 & 66 \\
\hline Widow & 6 & 19 \\
\hline Never married & 5 & 16
\end{tabular}




\begin{tabular}{lcc}
\hline Education & & \\
\hline High School & 5 & 17 \\
\hline Vocational School & 5 & 16 \\
\hline Undergraduate & 16 & 49 \\
\hline Graduate & 6 & 18 \\
\hline \multicolumn{2}{l}{ Number of Children } & \\
\hline 1 & 14 & \\
\hline 2 & 13 & 45 \\
\hline 3 & 5 & 40 \\
\hline
\end{tabular}

As it is indicated at Table 2, 22 participants (70\%) work at private sector while 7 of total 32 (23\%) work at public sector and the remaining 2 (7\%) are self-employed. 5 participants (15\%) work less than 40 hours per week while 15 of total (48\%) work 40 hours and 9 participants (27\%) work 45 hours. The remaining 3 participants (11\%) work longer than 45 hours per week. 6 participants (17\%) have less than 2 free days per week while 25 of total $(77 \%)$ have 2 free days and the remaining 1 participant ( $2 \%)$ has more than 2 days per week. 12 participants (37\%) have less than 4 years of work experience while 10 of total (32\%) have 5 -14 years of work experience and the remaining 10 participants (31\%) have longer than 14 years of work experience. 11 participants (35\%) earn less than Turkish lira 3,500 per month while 10 of total (31\%) earn between 3,500 and 5,500 liras. The remaining 11 participants (35\%) earns more than 5,500 liras per month.

Table 2: Occupational Characteristics of Sampling

\begin{tabular}{lcl}
\hline & N & $\%$ \\
\hline Occupation Sector & 22 & \\
\hline Private & 7 & 70 \\
\hline Public & 2 & 23 \\
\hline Self-employed & & 7 \\
\hline Work hours per week & 5 & 15 \\
\hline Less than 40 hours & 15 & 48 \\
\hline 40 hours & 9 & 27 \\
\hline 45 hours & 3 & 11 \\
\hline Longer than 45 hours & & \\
\hline Free days per week & 6 & 17 \\
\hline Less than 2 days & 25 & 77 \\
\hline 2 days & 1 & 32 \\
\hline More than 2 days & 10 & \\
\hline Work experience & 12 & 37 \\
\hline 4 years & 10 & \\
\hline $5-14$ years & & \\
\hline $15 \leq$ & & \\
\hline Monthly Income & & \\
\hline
\end{tabular}




\begin{tabular}{lll}
3500 Turkish lira $\geq$ & 11 & 35 \\
\hline $3501-5500$ & 10 & 31 \\
\hline $5501 \leq$ & 11 & 35
\end{tabular}

The in-depth interviews were a minimum of 65 minutes and a maximum of 90 minutes. The participants had children ages $3-11$. The age of the single working mothers who volunteered to participate in the qualitative research varied between 32 to 48.5 participants worked less than 40 hours per week. In comparison, 15 of them worked 40 hours, and 9 participants worked 45 hours. The remaining 3 participants worked longer than 45 hours per week. 7 participants had less than 2 free days per week, while 25 had 2 free days per week. 12 participants had less than 4 years of work experience, while 10 of them had 5-14 years of work experience, and the remaining 10 participants had more than 14 years of work experience.

To shed light on the emotional stability of single working mothers, open-ended questions were targeted to evaluate how:

- emotionally drained participants feel regarding their work

- drained they feel after work

- $\quad$ fatigued they think when they wake up in the morning

- $\quad$ strained they feel while they are working

- $\quad$ burned out they feel regarding their work

- $\quad$ frustrated they are with their job

- $\quad$ hard they work

- $\quad$ stressed they are

In the second part, open-ended questions regarding personal accomplishment aimed to evaluate how:

- $\quad$ easily they understand people's (particularly their children's) feelings

- $\quad$ effectively they deal with (particularly their children's) problems

- $\quad$ positively they influence others' (particularly their children's) lives

- $\quad$ energetic they feel

- easily they create a relaxed atmosphere at work and home

- worthwhile they feel

- calmly they deal with emotional problems at work and home

In the third part, intending to evaluate the resilience, open-ended questions were targeted to determine how:

- $\quad$ they treat people at work and home

- callous they feel

- emotionally hardened they feel about their job

- much they care about their work and children

- $\quad$ they feel when people at work and home blame them for an unrelated issue

In the last part, open-ended questions about involvement were asked to evaluate how:

- $\quad$ similar they feel to people at work and home 
- $\quad$ personally involved they feel with their children's problems and problems at work

- $\quad$ uncomfortable, they feel with the way they treat their children and people at work.

\section{FINDINGS AND DISCUSSIONS}

The research was conducted with 32 single mothers working in private companies in different industries in Istanbul. Participa nts were chosen from companies that employ more than 200 people.

Participants seemed divided between their roles at work and life. They place the highest value on their parenting role while also being committed to their work roles. However, they think they spend the most amount of time at work and spend insufficient time on parenting. Working single mothers believe their work roles have a heavier weight in their lives than their parenting role, but they believe their parenting roles also have great importance. As expected, the significance of work declines and the weight of family role rises as the number of children increases. On the contrary, as the education level increases, the work role's importance also increases, and the family role's weight declines. This is significantly related to career ambition and economic capability to employ assistants in the home.

Younger participants see their working roles as having a heavier weight in their lives. As an interesting observation, participants who are older than 40 years of age see their working roles as having heavier weight in their lives than participants who are between the age of 30 to 40 . This is particularly related to higher expenditure requirements for babies (younger participants have younger children) and young adults (elder participants' children are younger adults who need university education or marriage expenditures) compared to teenagers. It is also related to higher career expectations at early ages for younger participants and pressure to have enough savings for the pensionary period when it comes to the older age group. As work experience increases, the weight of the work role on participants' lives declines, but the family's role is mixed. Newcomers and seniors place higher importance on work roles compared to those who have mid-level experience.

Participants think their responsibilities at work have a more significant impact on their duties at home than the impact of their parenting responsibilities does on their responsibilities at work. It should be noted that they think both sides have moderate impacts on each other. The older age groups see their duties as having a higher impact on their family lives than the middle and younger age groups, but it is still seen as having a moderate impact. The younger age group sees their family responsibilitie sas having the highest impact on their work responsibilities, but it is still seen as a low impact. This is mainly related to a higher $\mathrm{c}$ are requirement for babies. As an interesting observation, participants who have more than one child see their work responsibilit ies and home affect each other at lower levels. This is mainly related to having more experience in the parenting role. Education level does not significantly impact the bilateral impact between the work role and family role.

The most dominant emotion participants feel is emotional exhaustion, significantly dominating all other emotions. The feeling of personal accomplishment comes next, and the sense of depersonalization has the lowest significance. It should be noted that all surfaces are low, suggesting dominant depersonalization. The older age group has the highest level of emotional exhaustion, while the younger age group has the highest level of depersonalization and feelings of personal accomplishment. As the number of children increases, emotional exhaustion and personal accomplishment decline while depersonalization increases. This is significantly related to rising altruism which comes with each additional child. As the education level increases, all partic ipants feel emotional exhaustion, depersonalization, and personal accomplishment decline.

Participants feel strong support from their social circles while also feeling moderate support from their organizations. The younger age group feels the most increased support from their social circles and organizations. Greater support from social circles is significantly related to younger parents. In comparison, greater support from organizations is related to sympathy/empathy for the responsibilities of taking care of babies and young children. The older age group feels lower support from their organizations and higher support from their social circles than the middle age group. This is significantly related to the negative attitud e towards older employees in Turkey and support from older children. As the number of children or education level increases, feelings of social and organizational support decline.

The literature supports the findings in this study that women without children have substantially higher occupational participation than women with children; contrary to this, women with younger children outperformed women with older children (Balaji, 2014). This is strongly linked to our finding that the more time and energy spent on caring for children (younger participants have younger children) affect parents' labor market appraisal, especially mothers with younger children. Young mothers seem to be more 
ambitious in the business environment even though physically they get tired more than the working mothers with older children. Being single also increases the level of motivation because young single working mothers have more responsibilities.

Single working mothers seemed to have a divided identity at work and in life. They gain the highest value in their caregiving position at home while raising children. However, they are still regular employees and have no significant difference from other colleagues. Single working mothers feel less significant in the business environment even though they feel that they spend mo re time at work than the time they spend with their children. According to Barnett \& Marshall (1992), if the educational level increases, the job role's weight increases for single mothers. Therefore, the weight of the parental role decreases comparatively. This is primarily associated with career ambition and the economic capacity to hire assistants to help at home.

In addition to the quantitative problems of total working hours, a significant debate has emerged that the more qualitative issues of whether playing multiple roles are beneficial or detrimental to one's well-being. Previous studies have generally supported the idea of role enhancement from a research perspective, namely that various roles increase the strength, reputation, wealth, and emotional satisfaction of an individual (Waldron \& Jacobs, 1989; Arber, 1991; Roxburgh, 1997; Kopp \& Ruzicka, 1993).

Another essential finding is that younger participants see their work roles as having greater weight in their lives, while participants older than 40 see their work roles as having greater importance. This is linked to higher early-age career aspirations for younger participants and pressure for the elderly to have adequate savings for their retirement. As work experience increases, the job position's weight on participants' lives decreases (Hibbard \& Pope, 1991). Compared to those who have mid-level experience, beginners and seniors see a more significant meaning in their work positions.

In this study, there was no evidence of the single working mothers having feelings of guilt. This finding will give the literature and future studies a fresh perspective. This research's incongruency with the previous literature can be due to the social and peer pressure on single mothers in Turkey. This incongruency caused by social anxiety should be researched more thoroughly in the following studies.

Emotional exhaustion is the most dominant emotion participants experience, significantly dominating all other emotions. Next comes the sense of personal success, with the feeling of depersonalization being experienced the least. It should be noted th at indicating dominant depersonalization for all participants is insufficient. The highest level of mental fatigue is experienced i $\mathrm{n}$ the older age group, while the younger age group has the highest depersonalization levels. Emotional exhaustion and personal achievement decrease as the number of children increases. There is a significant link to increasing altruism for each additional child when the participants have a higher level of education, both mental fatigue, depersonalization, and personal detachment decline.

\section{CONCLUSION}

Research results suggested that demographic factors such as age, education level, and work experience impact life -work balance and resilience at single working mothers' work. The number of children also has a direct impact. Results are mainly parallel with previous research findings, suggesting that women from higher socioeconomic levels are more comfortable with their resilience at work and work-life balance practices. Accordingly, the level of education positively impacts women's resilie nce and leads to more balanced/satisfying lives. Also, newcomers face more significant problems compared to experienced single working mothers.

Additionally, single working mothers also feel divided between their responsibilities at work and home in paral lel with other women. In line with previous research, single working mothers also feel exhausted and depersonalized. Emotional exhaustion increases as age increases, while depersonalization is seen higher in younger age groups.

This paper also contributes to the literature by introducing a perspective from single-mothers' idiosyncratic problems and practices regarding life-work balance and resilience at work. It also underlines that a gender perspective is required in organizational sciences on the concepts in question and the necessity of developing a more humanistic approach in labor force research.

Single working mothers suffer from a lack of counterparts who can listen and consider their problems and solution proposals. Their demands cover a wide range, including better working conditions, higher education opportunities, kindergartens, and child allowances. They are aware of their problems and necessary solutions, but the problem is that they do not have the power to make their employers listen to their demands. They are not aware of others having similar issues to their own therefore do not 
see the importance of coming together and the possibility of forming a union. Due to strict individualization, they feel lone ly in their struggle with life, work, and children.

Many of these findings can be exciting for academicians who are eager to understand working mothers and searching for ways to improve their work-life balance and performance at work. Additionally, the exploratory research findings can be studie $d$ on an affirmative basis to see if the outcomes will be similar for a more comprehensive sample range. The sample of 32 single working mothers in this study is a limitation and can be extended to retrieve deeperinsights for working mothers in different sectors. The results could be significantly different for single working mothers in the public sector.

Focusing only on the private sector is one of the significant limitations of this study. Subsequent studies can be conducted qualitatively or quantitatively to understand single working mothers' work-life balance in a governmental sector as there can be an entirely different employer mentality.

\section{REFERENCES}

Akkan, B., and Serim, S. (2018) Work and family reconciliation in Turkey: young women as a vulnerable group in the labour market. Research and Policy on Turkey 3(2): 173-186.

Alniacik, A., Altan-Olcay, O., Deniz, C., and Gokşen, F. (2017) Gender Policy Architecture in Turkey: Localizing Transnational Discourses of Women's Employment. Social Politics 24(3): 298-323.

Arber, S. (1991). Class, paid employment and family roles: making sense of structural disadvantage, gender and health status. Social science \& medicine, 32(4), 425-436.

Bardoel, E. A., Pettit, T. M., De Cieri, H., and McMillan, L. (2014) Employee resilience: An emerging challenge for HRM. Asia Pacific Journal of Human Resources 52(3): 279-297.

Berkman, L. F., Buxton, O., Ertel, K., and Okechukwu, C. (2010) Managers' practices related to work-family balance predict employee cardiovascular risk and sleep duration in extended care settings. Journal of Occupational Health Psychology 15(3): 316-329.

Berryhill, M. B., and Durtschi, J. A. (2016) Understanding Single Mothers' Parenting Stress Trajectories. Marriage \& Family Review 53(3): 227245.

Bespinar, F. U. (2010) Questioning agency and empowerment: Women's work-related strategies and social class in urban Turkey. Women's Studies International Forum 33(6): 523-532.

Bianchi, S. M., and Milkie, M. A. (2010) Work and family research in the first decade of the 21st century. Journal of Marriage and Family $72: 705-$ 725.

Bottrell, D. (2013) Responsibilised Resilience? Reworking Neoliberal Social Policy Texts. M/C Journal 16(5).

Brady, D. and Burroway, R. (2012) Targeting, Universalism and Single Mother Poverty: A Multi-Level Analysis Across 18 Affluent Democracies. Demography 49: 719-746.

Brand, J. E., and Thomas, J. S. (2014) Job displacement among single mothers: Effects on children's outcomes in young adulthood. American Journal of Sociology 119: 955-1001.

Britt, T., Shen, W., Sinclair, R., Grossman, M., and Klieger, D. (2016) How much do we really know about employee resilience? Industrial and Organizational Psychology 9(2): 378-404.

Calas, B., and Smircich, L. (2014) Engendering the organizational: feminist theorizing and organizational studies, P. Adler, P. Gay, G. Morgan, and M. Reed (Eds), The Oxford Handbook of Sociology, Social Theory, and Organization Studies: Contemporary Currents, Oxford: Oxford University Press.

Carmeli, A., Friedman, Y., \& Tishler, A. (2013) Cultivating a resilient top management team: The importance of relational connections and strategic decision comprehensiveness. Safety Science, 51(1): 148-159.

Chatman, D. (2015) Pregnancy, Then It's "Back to Business." Feminist Media Studies 15(6): 926-941.

Drange, N., Havnes, T., and Sandsor, A. M. J. (2016) Kindergarten for All: Long Run Effects of a Universal Intervention. Economics of Education Review 53: 164-181.

Ermis Mert, A. (2018) Women at Work and in the Family: A Discussion on Reconciliation Policy Practices. International Journal of Law, Policy and the Family 32(1): 27-41. 
Fagan, C., and Walthery, P. (2011) Job quality and the perceived work-life balance fit between work hours and personal commitments: A comparison of parents and older workers in Europe. In S. Drobnic and A. M. Guillen (Eds.) Work-life balance in Europe: the role of job quality. Basingstoke: Palgrave Macmillan.

Gill, R., and Orgad, S. (2018). The Amazing Bounce-Backable Woman: Resilience and the Psychological Turn in Neoliberalism. Sociological Research Online 23(2): 477-495.

Gittell, J.H., Cameron, K., Lim, S., and Rivas, R. (2006) Relationships, layoffs, and organizational resilience. Journal of Applied Behavioral Science 42(3): 300-329.

Goksel, I. (2013) Female Labor Force Participation in Turkey: The Role of Conservatism. Women's Studies International Forum 41(1): 45-54.

Grant, J., and Guerin, P. B. (2018) Motherhood as Identity: African Refugee Single Mothers Working the Intersections. Journal of Refugee Studies 32(4): 583-604.

Halbesleben, J.R.B., and Buckley, R.M. (2004) Burnout in organizational life. Journal of Management 30: 859-879.

Hancioglu, M., and Hartmann, B. (2014) What makes single mothers expand or reduce employment? Journal of Family and Economic Issues 35: 27-39.

Hansen, S. (2017). Women suffering at work. The Resilience Institute. Retrieved from https://resiliencei.com/2017/02/women-suffering-work/.

Harrison, E. (2013). Bouncing back? Recession, resilience and everyday lives. Critical Social Policy, 33(1), 97-113.

Hibbard, J. H., \& Pope, C. R. (1991). Effect of domestic and occupational roles on morbidity and mortality. Social Science \& Medicine, 32(7), 805811.

ILO (International Labour Organization). (2003) Labour Act of Turkey. Retrieved from https://www.ilo.org/dyn/natlex/docs/ELECTRONIC/64083/77276/\%20F75317864/TUR64083\%20English.pdf.

Isaacs, A. J. (2014) Gender Differences in Resilience of Academic Deans. Journal of Research in Education 24(1): 112-119.

Isreal, A. L., Butler, T. C., and Garcia, R. A. (2017) An Exploratory Qualitative Study of Work-Life Balance Experiences of Mothers in Doctoral Programs. Journal of Student Affairs 17: 51-62.

Jeyaranyan, J., and Swaminathan, P. (1999). Resilience of Gender Inequities: Women and Employment in Chennai. Economic and Political Weekly 34(16/17): 2-11.

Johnsen, J. V., and Reiso, K. H. (2019) Economic Effects of Workfare Reforms for Single Mothers: Benefit Substitution and Labour Supply Responses. The Scandinavian Journal of Economics 122(2): 494-523.

KA.DER (Association to Support Women Candidates). (2020) 2019 Yerel Secimlerine Toplumsal Cinsiyet Esitligi Perspektifinden Bakmak (Looking at the 2019 local elections from gender equality perspective). Retrieved from http://ka-der.org.tr/wp-content/uploads/2020/01/KA.DER_SivilDusun_Kitapcik.pdf.

Kabasakal, H., Aycan, Z., Karakas, F., and Maden, C. (2011). Women in management in Turkey. Chapter in Davidson, M. J., and Burke, R. J. (Ed.) Women in management worldwide. London: Routledge.

Kaya Bahçe, S. A., \& Memiş, E. (2013). Estimating the impact of the 2008-09 economic crisis on work time in Turkey. Feminist Economics, 19(3), 181-207.

Keeney J., Boyd, E., Sinha, R., Westring, A., and Ryan, A. (2013) From "work-family" to "work-life": broadening our conceptualization and measurement. Journal of Vocational Behaviour 82(3): 221-237.

Knoef, M. and van Ours, J. C. (2016) How to Stimulate Single Mothers on Welfare to Find a Job: Evidence from a Natural Experiment. Journal of Population Economics 29: 1025-1061.

Kopp, R. G., \& Ruzicka, M. F. (1993). Women's multiple roles and psychological well-being. Psychological Reports, 72(3_suppl), 1351-1354.

Kossek, E.E., Pichler, S., Bonder, T., and Hammer, L.B. (2011) Workplace Social Support and Work-Family Conflict: A Meta-Analysis, Clarifying The Influence of General and Work-Family-Specific Supervisor Ad Organizational Support. Personnel Psychology 64(2): $289-313$.

Koubova, V., and Buchko, A. A. (2013) Life-work balance: Emotional intelligence as a crucial component of achieving both personal life and work performance. Management Research Review 36(7): 700-719.

Koyuncu, M., Burke, R. J., and Wolpin, J. (2012) Work-family conflict, satisfactions and psychological well-being among women managers and professionals in Turkey. Gender in Management: An International Journal 27(3): 202-213. 
Kroger, T. (2010) Lone mothers and the puzzles of daily life: do care regimes really matter? International Journal of Social Welfare 19(4): 390401.

Lane, L. (2011) Conceptualizing work-life balance in the Swedish life puzzle debate - is it just about time? In I. Hojer and S. Hojer (Eds.), Family, Everyday Life and Modernity. Goteborg: University of Gothenburg.

LDC (Leadership Development Center). (2018) Are women less resilient than men in the workplace? Retrieved from https://www.Idc.govt.nz/assets/Uploads/Women-reslience-Conversation-starter-230119. pdf.

Liang, L. A., Berger, U., and Brand, C. (2018) Psychosocial factors associated with symptoms of depression, anxiety and stress among single mothers with young children: A population-based study. Journal of Affective Disorders 242: 255-264.

Linnenluecke, M. K. (2017) Resilience in business and management research: A review of influential publications and a research agenda: Resilience in business and management research. International Journal of Management Reviews 19(1): 4-30.

Lott, Y., and Chung, H. (2016) Gender discrepancies in the outcomes of schedule control on overtime hours and income in Germany. European Sociological Review 32(6): 752-765.

Maitlis, S. (2011) Post-traumatic growth: A missed opportunity for positive organizational scholarship. In K.S. Cameron and G.M. Spreitzer (Eds.), The Oxford handbook of positive organizational scholarship. New York: Oxford University Press.

Maslach, C., \& Jackson, S. E. (1981) The Measurement of Experienced Burnout. Journal of Occupational Behavior 2: 99-113.

Milkie, M. A., Kendig, S. M., Nomaguchi, K. M., and Denny, K. E. (2010) Time with children, children's Well-being, and work-family balance among employed parents. Journal Marriage and Family 72(5): 1329-1343.

Mogstad, M., and Pronzato, C. (2012). Are lone mothers responsive to policy changes? Evidence from a workfare reform in a generous welfare state. The Scandinavian Journal of Economics 114: 1129-1159.

Montez, J., Sabbath, E., Glymour, M., and Berkman, L. (2014) Trends in work-family context among U.S. women by education level, $1976-2011$. Population Research and Policy Review 33: 629-648.

Mostert, K. (2009). The balance between work and home: The relationship between work and home demands and ill health of employed females. SA Journal Industrial Psychology 35(1): 145-152.

Nabavi, A., and Shahryari, M. (2012) Linkage between worksite support with work role expectation, role ambiguity and its effects on work-family conflict. Canadian Social Science 8(4): 112-119.

Noor, N. M., and Zainuddin, M. (2011) Emotional labor and burnout among female teachers: work-family conflict as mediator. Asian Journal of Social Psychology 14: 283-293.

Palinkas, L. A., Horwitz, S. M., Green, C. A., Wisdom, J. P., Duan, N., and Hoagwood, K. (2013) Purposeful sampling for qualitative data collection and analysis in mixed method implementation research. Administration and Policy in Mental Health and Mental Health Services Research 42: 533-544.

Palmer, M., Rose, D., Sanders, M., and Randle, F. (2012) Conflict between work and family among New Zealand teachers with dependent children. Teaching and Teacher Education 28(7): 1049-1058.

Robbins, L. R., and McFadden, J. R. (2003) Single Mothers: The Impact of Work on Home and the Impact of Home on Work. Journal of Family and Consumer Sciences Education 21(1): 1-10.

Roman, C. (2017) Between Money and Love: Work-family Conflict Among Swedish Low-income Single Mothers. Nordic Journal of Working Life Studies 7(3): 23-41.

Roth, H., Homer, C., and Fenwick, J. (2012) 'Bouncing back': How Australia's leading women's magazines portray the postpartum 'body'. Women Birth 25(3): 128-134.

Roxburgh, A. J. (1997). The missionary congregation, leadership, and liminality. A\&C Black.

Sanders, M. R., Stallman, H. M., and McHale, M. (2011) Workplace Triple P: A controlled evaluation of a parenting intervention for working parents. Journal of Family Psychology, 25: 581-590.

Savin-Baden, M., and Major, C. H. (2013) Qualitative research: The essential guide to theory and practice. New York, NY: Routledge.

Schrag, A., and Schmidt-Tieszen, A. (2014) Social support networks of single young mothers. Child and Adolescent Social Work Journal 31: 315327. 
Shirahase, S., and Raymo, J. M. (2014) Single Mothers and Poverty in Japan: The Role of Intergenerational Coresidence. Social Forces 93(2): 545569.

Smith, P., Caputi, P., and Crittenden, N. (2012) How are women's glass ceiling beliefs related to career success? Career Development International 17(5): 458-474.

Sojo, V., \& Wood, R. (2012) Resilience: Women's Fit, Functioning, and Growth at Work: Indicators and Predictors. Centre for Ethical Leadership. Retrieved from https://minerva-

access. unimelb.edu.au/bitstream/handle/11343/123773/Resilience\%20Women\%27s\%20Fit\%20Functioning\%20and\%20Growth\%20a t\%20Work _Report.pdf?sequence=1.

Spangler, N. W., Koesten, J., Fox, M. H., and Radel, J. (2012) Employer perceptions of stress and resilience intervention. Journal of Occupational \& Environmental Medicine 54(11): 1421-1429.

Sperlich, S., and Geyer, S. (2015) The impact of social and family-related factors on women's stress experience in household and family work. International Journal of Public Health 60: 375-387.

Tabassum, N., Shafique, S., Konstantopoulou, A., \& Arslan, A. (2019) Antecedents of women managers' resilience: conceptual discussion and implications for HRM. International Journal of Organizational Analysis 14-43.

Tomlinson, J., and Durbin, S. (2010) Female Part time managers, work life balance, career aspirations and career mobility. Equality, Diversity, and Inclusion: An international Journal 29(3): 255-270.

Torchia, M., Calabro, A., and Huse, M. (2011) Women Directors on Corporate Boards: From Tokenism to Critical Mass. Journal of Business Ethics 102(2): 299-317.

TUIK (Turkish Statistical Institute). (2020) Women in Statistics, 2019. Retrieved from

http://www.turkstat.gov.tr/PreHaberBultenleri.do?id=33732.

Turner, S. B. (2014) The resilient nurse: An emerging concept. Nurse Leader 12(6): 71-90.

Vanhove, A. J., Herian, M. N., Perez, A. U., Harms, P. D., and Lester, P. B. (2015) Can resilience be developed at work? A meta-analytic review of resilience-building programme effectiveness. Journal of Occupational and Organizational Psychology 89(2): $278-307$.

Waldron, I., \& Jacobs, J. A. (1989). Effects of multiple roles on women's health-evidence from a national longitudinal study. Women \& health, 15(1), 3-20.

Walker, J., and Cooper, M. (2011) Genealogies of resilience: From systems ecology to the political economy of crisis adaptation. Security Dialogue 42(2): 143-160.

WEF (World Economic Forum). (2020) Global Gender Gap Report 2020. Retrieved from http://www3.weforum.org/docs/WEF_GGGR_2020.pdf.

Windle, G., Bennett, K. M., and Noyes, J. (2011) A methodological review of resilience measurement scales. Health and Quality of Life Outcomes 9(1): 1-18.

Winwood, P. C., Colon, R., and McEwen, K. (2013) A practical measure of workplace resilience: Developing the Resilience at Work Scale. Journal of Occupational and Environmental Medicine 55(10): 1205-1212.

Witmer, H. (2019) Degendering organizational resilience - the Oak and Willow against the wind. Gender in Management 34(6): 510-528.

WJP (World Justice Project). (2020) Rule of Law Index 2020. Retrieved from https://worldjusticeproject.org/sites/default/files/documents/WJPROLI-2020-Online_0.pdf.

Wolfson, N. E., and Mulqueen, C. (2016) Advancing employee resilience research: Additional thoughts. Industrial and Organizational Psychology 9(2): 452-456.

Youngblut, J. M., Brady, N. R., Brooten, D., and Thomas, D. J. (2000) Factors influencing single mother's employment status. Health Care for Women International 21(2): 125-136. 